\title{
ANALISIS POTENSI, EFEKTIFITAS, EFISIENSI, DAN KONTRIBUSI PAJAK REKLAME TERHADAP PENERIMAAN PAJAK DAERAH DI KABUPATEN MINAHASA UTARA
}

\author{
Raymond R. Korengkeng ${ }^{1}$, Herman Karamoy ${ }^{2}$, Winston Pontoh ${ }^{3}$ \\ ${ }^{123}$ Fakultas Ekonomi dan Bisnis, Jurusan Akuntansi, Universitas Sam Ratulangi, Jl.Kampus Bahu, Manado, \\ 95115, Indonesia \\ E-mail : raymondkorengkeng.rk@gmail.com
}

\begin{abstract}
Local taxes are levied by the local government and are used to finance the implementation of local government and regional development. With the enactment of local taxes, it is expected that local governments can obtain significant financial revenue posts. As one type of local taxes, advertisement tax is considered capable of increasing the financial income of each region. The purpose of this research is to know the potential of advertisement tax, the level of effectiveness and efficiency as well as to know the contribution of advertisement tax as a source of local tax revenue in North Minahasa District. The analytical method used is descriptive.. The results show the potential of advertisement tax revenues in 2017 approximately Rp. 1,250,560,290 calculated on the basis of an analysis of realization increases. The level of advertisement tax effectiveness between 2012-2016 tends to fluctuate but shows the criteria of "very effective" in 2015 with a percentage of $118.16 \%$ and 2016 of 199.59\%. The level of advertisement tax effectiveness is "very effective" because it does not cost in its implementation. While the contribution of advertisement tax 2012-2016 "very less" with a percentage of $0.5 \%-3.32 \%$ of local tax revenues. The collection system should be supervised and controlled to increase acceptance and re-registration of taxpayers and sanctions in order to fulfill the potential.
\end{abstract}

Keyword: advertisement tax, local tax, potential, effectiveness, efficiency, contribution

\section{PENDAHULUAN}

\section{Latar Belakang Masalah}

Negara Indonesia saat ini sedang giat-giatnya mendorong pertumbuhan ekonomi. Untuk mendorong pertumbuhan ekonomi, pemerintah harus gencar melakukan pembangunan secara merata di berbagai sektor Dalam mencapai pembangunan yang merata, diperlukan campur tangan dari setiap daerah dikarenakan kondisi geografis Indonesia yang terdiri dari pulau-pulau. Maka dari itu dalam mencapai tujuan tersebut pemerintah memberikan kemandirian dan keleluasaan bagi setiap daerah untuk mengurus rumah tangganya sendiri atau dalam kata lain sering disebut Otonomi Daerah. Sumber-sumber pendapatan daerah menurut Undang-Undang Nomor 32 Tahun 2004 terdiri atas Pendapatan Asli Daerah (PAD), dana perimbangan, dan lain-lain pendapatan daerah yang sah.

Pendapatan Asli Daerah (PAD) merupakan katalisator untuk mengukur derajat kemandirian suatu daerah. Semakin besar penerimaan PAD suatu daerah maka semakin rendah tingkat ketergantungan pemerintah daerah tersebut terhadap pemerintah pusat. Sumber penerimaan daerah yang signifikan dalam PAD adalah pajak daerah.

Dalam kaitannya dengan pajak secara umum, pajak daerah dipungut oleh pemerintah daerah dan digunakan untuk membiayai penyelenggaraan pemerintahan daerah dan pembangunan daerah. Pajak daerah dapat tidak dipungut apabila potensinya kurang memadai atau disesuaikan dengan peraturan daerah. 
Sebagai salah satu jenis dari pajak kabupaten/kota, pajak reklame dianggap mampu meningkatkan pendapatan keuangan setiap daerah. Pajak Reklame sendiri merupakan pajak yang dikenakan atas penyelenggaaraan reklame. Sedangkan reklame adalah media yang dirancang untuk tujuan komersial seperti memperkenalkan dan mempromosikan barang dan jasa kepada masyarakat secara umum.

Walaupun mengalami peningkatan yang signifikan, secara keseluruhan target dan realisasi dari pajak reklame cenderung rendah dibanding dengan jenis pajak daerah lainnya. Rendahnya kontribusi pajak reklame ini membuktikan bahwa pajak reklame bukan merupakan pajak unggulan di Kabupaten Minahasa Utara.

Apabila melihat lokasi geografis Kabupaten Minahasa Utara yang strategis, dimana berada di antara 2 kota yang menjadi gerbang utama regional, nasional dan internasional, yaitu Pelabuhan Bitung dan Bandar Udara Internasional Sam Ratulangi, serta jalur lalu lintas perekonomian antar kabupaten/kota, seharusnya pajak reklame bisa menjadi pajak unggulan. Sebagai daerah perlintasan dan daerah persinggahan, Kabupaten Minahasa Utara banyak dilintasi pengguna pengguna jalan. Kondisi tersebut tentunya akan dimanfaatkan para pengembang baik dari sektor industri, sektor dagang, dan sektor jasa untuk memasarkan berbagai produk mereka. Salah satu media pemasaran yang paling diminati adalah reklame. Reklame dianggap sebagai media yang paling efektif karena bisa diakses masyarakat secara umum. Selain itu, reklame juga digunakan sebagai tanda pengenal tempat usaha. Secara sederhana dapat disimpulkan bahwa reklame sangat diperlukan segala jenis usaha dalam memperkenalkan atau memasarkan produknya. Maka bisa dikatakan prospek dan potensi pajak reklame sangat besar sehingga perlu untuk diperhatikan oleh pemerintah daerah.

\section{Tujuan Penelitian}

Tujuan dari penelitian ini adalah untuk mengetahui:

1. Potensi pajak reklame di Kabupaten Minahasa Utara.

2. Tingkat efektifitas pajak reklame di Kabupaten Minahasa Utara dari tahun 2012-2016.

3. Efisiensi pajak reklame di Kabupaten Minahasa Utara.

4. Kontribusi pajak reklame terhadap penerimaan pajak daerah Kabupaten Minahasa Utara dari tahun 2012-2016.

\section{TINJAUAN PUSTAKA}

\section{Akuntansi Pajak}

Waluyo (2014:35) menjelaskan bahwa dalam menetapkan besarnya pajak terutang tetap mendasarkan laporan keuangan yang disusun oleh perusahaan, mengingat dalam ketentuan perundang-undangan perpajakan terdapat aturan-aturan khusus yang berkaitan dengan akuntansi, yaitu masalah konsep transaksi dan peristiwa keuangan, metode pengukurannya, serta pelaporannya yang ditetapkan undang undang. Akuntansi pajak hanya digunakan untuk mencatat transaksi yang berhubungan dengan perpajakan (Mosal, 2013). Akuntansi pajak tercipta karena adanya suatu prinsip dasar yang diatur dalam undang-undang perpajakan dan pembentukannya dipengaruhi oleh fungsi perpajakan dalam mengimplementasikan sebagai kebijakan pemerintah (Waluyo, 2014:42).

\section{Pajak}

Prof. Dr. Soemitro, S.H dalam bukunya Mardiasmo (2016:3) menyatakan "pajak adalah iuran rakyat kepada kas negara berdasarkan undang-undang (yang dapat dipaksakan) dengan tiada mendapat jasa timbal (kontraprestasi) yang langsung dapat ditunjukkan dan yang digunakan untuk membayar pengeluaran umum". N. J. Feldmann dalam Suandy (2014:8) mengemukakan "Pajak adalah prestasi yang dipaksakan sepihak oleh dan terutang kepada 
pengusaha menurut norma-norma yang ditetapkannya secara umum, tanpa adanya kontraprestasi, dan semata-mata digunakan untuk menutup pengeluaran umum".

\section{Fungsi Pajak}

Mardiasmo (2016:4) mengemukakan pajak mempunyai dua fungsi, yaitu:

1. Fungsi anggaran (budgetair)

Sumber dana bagi pemerintah untuk membiayai pengeluaran-pengeluarannya.

2. Fungsi mengatur (regulerend)

Alat untuk mengatur atau melaksanakan kebijakan pemerintah dalam bidang sosial dan ekonomi.

Dalam perkembangannya, fungsi pajak dapat dikembangkan dan ditambah dua fungsi lagi (Ilyas \& Burton, 2013:13-14), yaitu:

1. Fungsi Demokrasi

Wujud sistem gotong royong, termasuk kegiatan pemerintahan dan pembangunan demi kemaslahatan manusia.

2. Fungsi Redistribusi

Menekankan pada unsur pemerataan dan keadilan dalam masyarakat.

\section{Pajak Daerah}

Menurut Samudra (2015:68) pajak daerah adalah pajak yang dipungut daerah berdasarkan peraturan pajak yang ditetapkan oleh daerah untuk kepentingan pembiayaan rumah tangga pemerintah daerah tersebut. Ada beberapa ciri yang melekat dalam pengertian pajak daerah, baik menurut undang-undang yang terdahulu maupun yang berlaku sekarang, yaitu:

1. Pajak daerah dapat berasal dari pajak asli daerah maupun pajak negara yang diserahkan kepada daerah sebagai pajak daerah.

2. Pajak daerah dipungut oleh daerah terbatas di dalam wilayah administratif yang dikuasainya.

3. Hasil pungutan pajak daerah dipergunakan untuk membiayai urusan rumah tangga daerah atau untuk membiayai pengeluaran daerah sebagai badan hukum.

4. Pajak daerah dipungut oleh daerah berdasarkan kekuatan Peraturan Daerah (Perda), maka sifat pemungutan pajak daerah dapat dipaksakan kepada masyarakat yang wajib membayar dalam lingkungan administratif kekuasaannya.

\section{Jenis-Jenis Pajak Daerah}

Pajak daerah terdiri atas dua jenis pajak, yaitu pajak yang dipungut oleh pemerintah provinsi, dan pajak yang dikelola oleh kabupaten/kota. Berdasarkan Undang-Undang Nomor 28 Tahun 2009 tentang Pajak Daerah dan Retribusi Daerah, jenis-jenisnya adalah sebagai berikut:

Pajak Provinsi, antara lain:

1. Pajak Kendaraan Bermotor;

2. Bea Balik Nama Kendaraan Bermotor;

3. Pajak Bahan Bakar Kendaraan Bermotor;

4. Pajak Air Permukaan; dan

5. Pajak Rokok.

Sedangkan pajak kabupaten/kota, antara lain:

1. Pajak Hotel;

2. Pajak Restoran;

3. Pajak Hiburan;

4. Pajak Reklame; 
5. Pajak Penerangan Jalan;

6. Pajak Mineral bukan Logam dan Batuan;

7. Pajak Parkir;

8. Pajak Sarang Burung Walet;

9. Pajak Bumi dan Bangunan Pedesaan dan Perkotaan; dan

10. Bea Perolehan Hak atas Tanah dan Bangunan.

\section{Pajak Reklame}

Undang-Undang Nomor 28 Tahun 2009 tentang Pajak Daerah dan Retribusi Daerah menyatakan bahwa Pajak Reklame adalah pajak atas penyelenggaraan reklame. Sedangkan reklame itu sendiri adalah benda, alat, perbuatan, atau media yang bentuk dan corak ragamnya dirancang untuk tujuan komersial memperkenalkan, menganjurkan, mempromosikan, atau untuk menarik perhatian umum terhadap barang, jasa, orang, atau badan, yang dapat dilihat, dibaca, didengar, dirasakan, dan/atau dinikmati oleh umum.

\section{Dasar Hukum Pemungutan Pajak Reklame}

Adapun dasar hukum dari pemungutan pajak reklame adalah sebagai berikut:

1. Undang-Undang Nomor 28 Tahun 2009 tentang Pajak Daerah dan Retribusi Daerah.

2. Undang-Undang Nomor 34 Tahun 2000 yang merupakan perubahan atas Undang-Undang Nomor 18 Tahun 1997 tentang Pajak Daerah dan Retribusi Daerah.

3. Peraturan Pemerintah Nomor 55 Tahun 2016 tentang Ketentuan Umum dan Tata Cara Pemungutan Pajak Daerah.

4. Peraturan Pemerintah Nomor 65 Tahun 2001 tentang Pajak Daerah.

5. Peraturan Daerah (kabupaten/kota) yang mengatur tentang Pajak Reklame.

6. Keputusan Bupati/Walikota yang mengatur tentang Pajak Reklame sebagai aturan penyelenggaraan peraturan daerah tentang Pajak Reklame pada Kabupaten/Kota yang terkait.

\section{Jenis Reklame}

Berikut adalah jenis-jenis reklame menurut Samudra (2015:217):

1. Reklame papan/billboard/videotron/megatron dan sejenisnya;

2. Reklame kain;

3. Reklame melekat stiker;

4. Reklame selebaran;

5. Reklame berjalan, termasuk pada kendaraan;

6. Reklame udara;

7. Reklame apung;

8. Reklame suara;

9. Reklame film/slide;

10. Reklame peragaaan.

\section{Tarif Pajak dan Dasar Pengenaan Pajak Reklame}

Undang-Undang Republik Indonesia Nomor 28 Tahun 2009 tentang Pajak Daerah dan Retribusi Daerah, menyatakan bahwa Tarif Pajak Reklame ditetapkan paling tinggi sebesar $25 \%$ (dua puluh lima persen). Berikut adalah cara perhitungan pajak reklame:

Pajak Reklame $=$ Dasar Pengenaan Pajak $\times$ Tarif Pajak

Dasar pengenaan pajak reklame adalah Nilai Sewa Reklame. Nilai Sewa Reklame oleh Samudra (2015:221) dihitung berdasarkan:

1. Besarnya biaya pemasangan reklame; 
2. Besarnya biaya pemeliharaan reklame;

3. Lama pemasangan reklame;

4. Nilai strategis lokasi;

5. Jenis reklame.

\section{Potensi}

Potensi adalah gambaran dari hasil yang didapatkan yang masih bisa dikembangkan sesuai dengan "keadaan yang sebenarnya". Langford dan Ohlenburg (2016:6) mendefinisikan potensi pajak sebagai jumlah maksimum penerimaan pajak yang bisa meningkat pada titik tertentu, tergantung pada karakteristik yang berlaku.

\section{Efektifitas}

Efektifitas menunjukkan kesuksesan atau kegagalan dalam pencapaian suatu tujuan. Pada dasarnya efektifitas membandingkan antara hasil yang didapatkan (output) dengan sasaran yang diharapkan. Suatu organisasi, program, atau kegiatan dinilai efektif apabila output yang dihasilkan bisa memenuhi tujuan yang diharapkan atau dikatakan spending wisely (Nordiawan \& Hertianti, 2014:162). Efektifitas menekankan pada hasil yang dicapai.

\section{Efisiensi}

Nordiawan dan Hertianti (2014:161) berpendapat bahwa "Suatu organisasi, program, atau kegiatan dikatakan efisien apabila mampu menghasilkan output tertentu dengan input serendah-rendahnya, atau dengan input tertentu mampu menghasilkan output sebesarbesarnya (spending well)".

\section{Kontribusi}

Dalam kaitannya dengan pajak reklame, kontribusi memiliki arti sejauh mana hasil penerimaan pajak reklame yang terkumpul di suatu daerah dibandingkan dengan keseluruhan jumlah penerimaan pajak daerah yang diterima.

\section{Penelitian Terdahulu}

Prastika (2015) dalam penelitian yang berjudul Analisis Efektivitas Pendapatan Pajak Reklame dan Kontribusinya pada Pendapatan Pajak Daerah. Tujuan penelitian ini untuk menganalisis efektivitas dan kontribusi Pajak Reklame terhadap Pendapatan Pajak Daerah di Kota Malang. Metode yang digunakan dalam penelitian ini adalah metode deskriptif. Hasil penelitiannya tingkat efektivitas pajak reklame antara tahun 2010-2014 mengalami fluktuatif. Kontribusi pajak reklame terhadap pendapatan pajak daerah masih sangat rendah.

Midiyati (2014) dalam penelitian yang berjudul Analisis Efektifitas dan Efisiensi Pemungutan Pajak Reklame serta Kontribusinya terhadap Penerimaan Pajak Daerah. Tujuan Penelitian ini adalah menganalisis efektivitas dan efisiensi pajak reklame serta kontribusinya terhadap pajak daerah di Kota Semarang. Metode penelitian yang digunakan adalah metode deskriptif. Hasil penelitiannya pajak reklame antara tahun 2008-12 sangat efektif dan efisien. Sedangkan kontribusinya mengalami peningkatan tapi belum mencapai potensi yang ada.

Kobandaha (2016) dalam penelitian yang berjudul Analisis Efektivitas, Kontribusi dan Potensi Pajak Reklame dan Pajak Hotel Terhadap Pendapatan Asli Daerah Kota Kotamobagu. Tujuan penelitian ini untuk menganalisis efektivitas dan potensi pajak reklame dan pajak hotel di Kota Kotamobagu. Metode penelitian yang digunakan adalah metode deskriptif. Hasil penelitiannya penerimaan pajak reklame tergolong sangat efektif sedangkan pajak hotel efektif tapi mengalami penurunan di tahun terakhir. Kontribusi pajak reklame hanya sebesar $1,75 \%$ dan pajak hotel sebesar $1,25 \%$.

Lengkong (2015) dalam penelitian yang berjudul nalisis Potensi dan Efektivitas 
Pemungutan Pajak Reklame di Kota Bitung. Tujuan penelitiannya adalah mengetahui potensi pajak reklame yang dimiliki Kota Bitung serta tingkat efektifitas pajak. Metode penelitian yang digunakan adalah metode kuantitatif. Hasil penelitiannya penerimaan Pajak Reklame di Kota Bitung sudah sangat efektif dan melebihi target yang ditetapkan. Pajak Reklame juga memiliki potensi yang cukup besar.

\section{METODE PENELITIAN}

\section{Jenis Penelitian}

Penelitian ini termasuk pada jenis penelitian deskriptif. Adapun dalam penelitian ini peneliti akan menguraikan potensi sebenarnya dari pajak reklame, tingkat efektifitas, tingkat efisiensi, dan kontribusi pajak reklame terhadap penerimaan pajak daerah.

\section{Tempat dan Waktu Penelitian}

Penelitian ini berlokasi di Kantor Badan Keuangan Kabupaten Minahasa Utara. Proses Penelitian ini dilakukan pada bulan Februari 2017 sampai dengan selesai.

\section{Teknik Pengumpulan Data}

Dalam kegiatan penelitian yang akan dilaksanakan, terdapat beberapa metode yang digunakan dalam pengumpulan data.

1. Studi Lapangan (Field Research)

Teknik pengumpulan data ini dilaksanakan dengan cara melakukan observasi secara langsung, melaksanakan wawancara dengan pegawai dan pimpinan untuk memperoleh data, dan pengumpulan data melalui informasi tertulis berupa dokumentasi.

2. Studi Kepustakaan (Library Research)

Peneliti juga mencari dan memperoleh data yang diperlukan dengan membaca dan mempelajari literatur-literatur, jurnal-jurnal, dan buku-buku yang berhubungan dengan masalah yang diteliti.

\section{Metode Analisis Data}

Metode Analisis data yang digunakan dalam penelitian ini adalah menggunakan metode deskriptif. Metode deskriptif dapat dilakukan melalui analisis kualitatif dengan cara menggambarkan kenyataan atau keadaan-keadaan atas suatu objek dalam bentuk uraian kalimat berdasarkan keterangan-keterangan dari pihak-pihak yang berhubungan langsung dengan penelitian ini. Selain itu, peneliti juga melakukan analisis kuantitatif untuk menghitung kenaikan realisasi, potensi, efektifitas, efisiensi, dan kontribusi pajak reklame.

\section{HASIL PENELITIAN DAN PEMBAHASAN \\ Hasil Penelitian \\ Gambaran Umum Kabupaten Minahasa Utara}

Kabupaten Minahasa Utara merupakan kabupaten yang dibentuk dengan UndangUndang Nomor 55 Tahun 2003 dan diresmikan pada tanggal 7 Januari 2004. Minahasa Utara adalah salah satu kabupaten di Provinsi Sulawesi Utara. Ibukota Kabupaten Minahasa Utara adalah Airmadidi. Secara geografis Kabupaten Minahasa Utara terletak pada $1^{\circ} 17$ 51,93" LU-1 ${ }^{\circ} 56^{\prime}$ '41,03" LU dan $124^{\circ} 40^{\prime} 38,39^{\prime \prime}$ BT - $125^{\circ} 5^{\prime}$ ' 15,53” BT. Luas wilayah Kabupaten Minahasa Utara termasuk pulau-pulaunya adalah $1.059,244 \mathrm{~km}^{2}$ dengan garis pantai sepanjang 292,20 km. Jumlah penduduk sebesar 198.084 jiwa dengan kepadatan penduduk mencapai $187,01 \mathrm{jiwa} / \mathrm{km}^{2}$, rata-rata tiap $\mathrm{km}^{2}$ dihuni oleh sekitar 187 penduduk. 


\section{Gambaran Umum Badan Keuangan}

Badan Keuangan merupakan gabungan dari Badan Pengolahan Keuangan dan Barang Milik Daerah (BPKBMD) dan Dinas Pendapatan Daerah yang baru disahkan pada tanggal 1 Januari 2017.

\section{Gambaran Umum Pajak Reklame di Kabupaten Minahasa Utara}

Dasar hukum dari pelaksanaan dan pemungutan pajak reklame di Kabupaten Minahasa adalah Peraturan Daerah Nomor 4 Tahun 2015 dan Peraturan Bupati Nomor 34 Tahun 2016. Tarif yang dikenakan di setiap jenis pajak reklame di Kabupaten Minahasa Utara adalah sebesar 25\%. Dalam hal reklame yang diselenggarakan dengan produk rokok, maka akan dikenakan biaya tambahan sebesar $25 \%$ dari nilai pajak yang harus dibayarkan. Nilai Sewa Reklame di Kabupaten Minahasa Utara dihitung berdasarkan:

1. Nilai Strategis Lokasi;

a. Tempat perbelanjaan/keramaian umum bernilai $5 \%$.

b. Jalan umum bernilai $4 \%$.

c. Tempat usaha bernilai $3 \%$.

2. Ukuran/Satuan Media Reklame;

3. Jangka Waktu; dan

4. Harga Satuan Reklame.

Berikut adalah target dan realisasi pajak reklame di Kabupaten Minahasa Utara Tahun 2012-2016.

Tabel 1 Target dan Realisasi Pajak Reklame Kabupaten Minahasa Utara Tahun 20122016

\begin{tabular}{|c|c|c|}
\hline Tahun & Target (Rp.) & Realisasi (Rp.) \\
\hline 2012 & 87.100 .000 & 82.049 .473 \\
\hline 2013 & 95.810 .000 & 67.911 .563 \\
\hline 2014 & 200.000 .000 & 154.194 .985 \\
\hline 2015 & 107.724 .969 & 127.284 .701 \\
\hline 2016 & 500.000 .000 & 997.973 .258 \\
\hline
\end{tabular}

Sumber: Badan Keuangan Kabupaten Minahasa Utara

Tabel 1 dapat dilihat realisasi penerimaan pajak reklame cenderung fluktuatif dimana pada tahun 2012 sampai dengan tahun 2014 tidak mencapai target yang telah ditetapkan. Pada tahun 2012, realisasi hanya mencapai Rp. 82.049.473 dari target Rp. 87.100.000. Pada tahun 2013 sebesar Rp. 67.911.563 dari target sebesar Rp. 95.810.000, dan tahun 2014 realisasi sebesar Rp. 154.194.985 dari target Rp. 200.000.000. Pada tahun 2015 sebesar Rp. 127.284.701 dari target Rp. 107.724.969 yang ditetapkan, tahun 2016 realisasi penerimaan Rp. 997.973.258 dari target Rp. 500.000.000.

\section{Pembahasan}

\section{Potensi Pajak Reklame}

\section{Potensi Tahun Sebelumnya}

Berdasarkan hasil penelitian dan wawancara di objek penelitian, tidak ditemukan data yang spesifik mengenai jumlah papan reklame per jenis reklame, rata-rata ukuran reklame, dan rata-rata waktu pemasangan reklame. Oleh karena keterbatasan di atas, potensi pajak reklame di tahun-tahun sebelumnya yakni dari tahun 2012-2016 tidak dapat diketahui.

2. Potensi Penerimaan Tahun Berjalan

\section{a. Menghitung Kenaikan Realisasi Tiap Tahun}

(1) Tahun 2013=

$$
=-20,82 \%
$$



(2) Tahun 2014=
(3) Tahun 2015=
(4) Tahun 2016=

$$
\begin{aligned}
& =55,96 \% \\
& =-21,14 \% \\
& =87,24 \%
\end{aligned}
$$

b. Menghitung Rata-Rata Tingkat Kenaikan x $100 \%$

c. Menghitung Potensi Penerimaan Pajak Reklame Tahun 2017

$$
\begin{aligned}
2017 & =(100 \%+25,31 \%) \times \text { Rp. } 997.973 .258 \\
& =\text { Rp. } 1.250 .560 .290
\end{aligned}
$$

Jadi, dari analisis potensi yang telah dilakukan dengan menggunakan rumus di atas, dapat diketahui potensi penerimaan pajak reklame Kabupaten Minahasa Utara Tahun 2017 yang dapat diperoleh kira-kira sebesar Rp. 1.250.560.290. Realisasi penerimaan pajak reklame hingga Triwulan II Tahun 2017 tercatat sebesar hanya Rp. 293.679.359. Berdasarkan kondisi yang ada dimana penerimaan pajak reklame hingga Triwulan II masih di bawah 50\% dari gambaran potensi penerimaan yang dihitung, peneliti berkesimpulan realisasi penerimaan pajak reklame di Kabupaten Minahasa Utara yang akan diterima pada tahun 2017 cenderung kurang dan belum memenuhi gambaran potensi yang ada berdasarkan analisis kenaikan realisasi.

\section{Efektivitas Pajak Reklame}

Tabel 2 Efektifitas Pajak Reklame Kabupaten Minahasa Utara Tahun 2012-2016

\begin{tabular}{|c|c|c|c|c|}
\hline Tahun & Target (Rp.) & Realisasi (Rp.) & Efektifitas & Kriteria \\
\hline 2012 & 87.100 .000 & 82.049 .473 & $94,2 \%$ & Efektif \\
\hline 2013 & 95.810 .000 & 67.911 .563 & $70,88 \%$ & Kurang Efektif \\
\hline 2014 & 200.000 .000 & 154.194 .985 & $77,1 \%$ & Kurang Efektif \\
\hline 2015 & 107.724 .969 & 127.284 .701 & $118,16 \%$ & Sangat Efektif \\
\hline 2016 & 500.000 .000 & 997.973 .258 & $199,59 \%$ & Sangat Efektif \\
\hline
\end{tabular}

Sumber : Data diolah, 2017

Tabel 2 dapat dilihat tingkat efektifitas penerimaan pajak reklame Kabupaten Minahasa Utara tahun 2012-2016. Pada tahun 2012 sebesar 94,2\% sehingga dikategorikan efektif, tahun 2013 dan tahun 2014 sebesar 70,88\% dan 77,1\% dengan kategori kurang efektif. Sedangkan pada tahun 2015 dan tahun 2016 tergolong sangat efektif karena jauh melampaui target sebesar 118,16\% dan 199,59\%. Hal ini didasari atas mulai diberlakukannya Peraturan Daerah Nomor 4 Tahun 2015 yang memuat perubahan bobot dari Nilai Sewa Reklame yang menjadi dasar perhitungan pajak reklame.

\section{Efisiensi Pajak Reklame}

Berdasarkan hasil penelitian di objek penelitian, tidak ada biaya yang dikeluarkan dalam pemungutan pajak reklame. Hal ini berarti pelaksanaan pajak reklame di Kabupaten Minahasa Utara dapat dikatakan sangat efisien. 


\section{Kontribusi Pajak Reklame}

Tabel 3 Kontribusi Pajak Reklame Terhadap Pajak Daerah Kabupaten Minahasa Utara Tahun 2012-2016

\begin{tabular}{|c|c|c|c|c|}
\hline Tahun & $\begin{array}{c}\text { Realisasi } \\
\text { Pajak Reklame }\end{array}$ & $\begin{array}{c}\text { Realisasi } \\
\text { Pajak Daerah }\end{array}$ & Kontribusi & Kriteria \\
\hline 2012 & 82.049 .473 & 10.710 .695 .408 & $0,77 \%$ & Sangat Kurang \\
\hline 2013 & 67.911 .563 & 11.256 .793 .033 & $0,6 \%$ & Sangat Kurang \\
\hline 2014 & 154.194 .985 & 20.070 .101 .061 & $0,77 \%$ & Sangat Kurang \\
\hline 2015 & 127.284 .701 & 25.266 .469 .042 & $0,5 \%$ & Sangat Kurang \\
\hline 2016 & 997.973 .258 & 30.072 .989 .664 & $3,32 \%$ & Sangat Kurang \\
\hline
\end{tabular}

Sumber : Data diolah, 2017

Tabel 3 dapat dilihat kontribusi dari pajak reklame terhadap penerimaan pajak daerah dari tahun 2012 sampai tahun 2016 tergolong rendah dengan kriteria "sangat kurang". Hal ini ditunjukkan dengan prosentase kontribusi di antara 0,5\% - 3,32\%. Kurangnya kontribusi pajak reklame disebabkan penyelenggaraan reklame yang hanya bersumber dari jenis reklame papan/billboard/videotron/neonbox, reklame kain, dan reklame melekat/stiker.

\section{KESIMPULAN DAN SARAN}

\section{Kesimpulan}

1. Gambaran Potensi Penerimaan Pajak Reklame pada tahun 2017 yang dapat diperoleh kira-kira sebesar Rp. 1.250.560.290. Realisasi penerimaan pajak reklame hingga Triwulan II Tahun 2017 hanya sebesar Rp. 293.679.359 atau di bawah 50\% dari perhitungan potensi penerimaan berdasarkan analisis kenaikan realisasi. Dapat dikatakan realisasi penerimaan pajak reklame yang akan diperoleh pada tahun 2017 cenderung kurang dan belum memenuhi potensi yang ada.

2. Penerimaan Pajak Reklame di Kabupaten Minahasa Utara masih fluktuatif atau cenderung naik turun. Pada tahun 2012, tingkat efektifitas sebesar 94,2\%, tahun 2013 sebesar 70,88\%, dan tahun 2014 sebesar 77,1\%. Pada tahun 2015 dan 2016 penerimaan pajak reklame tergolong "sangat efektif" dengan prosentase sebesar 118,6\% dan 199,5\%. Dapat disimpulkan bahwa walaupun cenderung fluktuatif tapi penerimaan pajak reklame pada 2 tahun terakhir mengalami trend peningkatan. Naiknya penerimaan pada tahun 2016 secara signifikan didasari oleh perubahan bobot dari Nilai Sewa Reklame yang menjadi dasar perhitungan pajak reklame.

3. Pemungutan Pajak Reklame di Kabupaten Minahasa Utara dapat dikatakan sangat efisien karena pemungutan pajak reklame tidak mengeluarkan biaya.

4. Kontribusi Pajak Reklame terhadap Pajak daerah tergolong "sangat kurang". Kontribusi tahun 2012 sebesar 0,77\%, tahun 2013 sebesar 0,6\%, tahun 2014 sebesar 0,77\%, tahun 2015 sebesar 0,5\%, dan pada tahun 2016 sebesar 3,32\%. Walaupun kontribusi pada tahun 2016 mengalami peningkatan, namun dapat disimpulkan kontribusi pajak reklame sangat kecil dibanding kontribusi dari jenis pajak daerah lainnya.

5. Kurangnya kontribusi pajak reklame terhadap penerimaan pajak daerah salah satunya disebabkan oleh jumlah penyelenggaraan reklame itu sendiri yang hanya berasal dari reklame papan/billboard/videotron, reklame kain, dan reklame melekat/stiker.

\section{Saran}

1. Sistem Pemungutan harus terus diawasi dan lebih digiatkan lagi agar penerimaan Pajak Reklame terkontrol dan dapat ditingkatkan lagi sesuai potensi yang ada. 
2. Sebaiknya dilakukan sosialisasi yang lebih intensif dan persuasif kepada wajib pajak reklame dan masyarakat umum. Dengan pahamnya masyarakat akan pentingnya pajak, secara langsung akan membawa dampak positif dalam penerimaan pajak.

3. Badan Keuangan dapat melakukan pendataan ulang terhadap subjek pajak, objek reklame, dan masa perijinan reklame sehingga penerimaan yang didapatkan lebih maksimal dan penetapan target yang dilakukan lebih tepat. Selain itu dengan adanya pendataan ulang, penyelenggaraan reklame yang belum memiliki perijinan maupun yang memiliki tunggakan pajak bisa dipantau dan diberi sanksi.

4. Sebaiknya data mengenai jumlah per jenis reklame dari tahun ke tahun diarsipkan lebih spesifik sehingga nantinya dikemudian hari bisa dijadikan bahan analisis bagi pemerintah dalam menentukan target dan melihat potensi yang ada.

\section{DAFTAR PUSTAKA}

Ilyas, Wirawan dan Richard Burton. 2013. Hukum Pajak, Edisi 6. Penerbit : Salemba Empat, Jakarta.

Kobandaha, Rezlyanti. 2016. Analisis Efektivitas, Kontribusi dan Potensi Pajak Reklame dan Pajak Hotel Terhadap Pendapatan Asli Daerah Kota Kotamobagu. Fakultas Ekonomi dan Bisnis Universitas Sam Ratulangi.

Langford, Ben dan Tim Ohlenburg. 2016. Tax Revenue Potential And Effort (An Empirical Investigation). International Growth Centre Working Paper.

Lengkong, Triski Intan M. 2015. Analisis Potensi dan Efektivitas Pemungutan Pajak Reklame di Kota Bitung. Fakultas Ekonomi dan Bisnis Universitas Sam Ratulangi.

Mardiasmo. 2016. Perpajakan, Edisi Terbaru, Penerbit: CV. Andi Offset, Yogyakarta.

Midiyati, Meilyna N. 2012. Analisis Efektivitas Dan Efisiensi Pemungutan Pajak Reklame Serta Kontribusinya Terhadap Penerimaan Pajak Daerah. Fakultas Ekonomi dan Bisnis Universitas Dian Nuswantoro. Semarang.

Nordiawan, Deddi dan Ayuningtyas Hertianti. 2014. Akuntansi Sektor Publik. Penerbit: Salemba Empat, Jakarta.

Republik Indonesia. 2004. Undang-Undang Nomor 32 Tentang Pemerintahan Daerah.

Republik Indonesia. 2009. Undang-Undang Nomor 28 Tentang Pajak Daerah Dan Retribusi Daerah.

Prastika, Yolanda Nurlita. 2015. Analisis Efektivitas Pendapatan Pajak Reklame Dan Kontribusinya Pada Pendapatan Pajak Daerah. Fakultas Ilmu Administrasi, Universitas Brawijaya.

Samudra, Azhari Aziz. 2015. Perpajakan di Indonesia : Keuangan, Pajak dan Retribusi Daerah. Penerbit : Rajawali Pers, Jakarta.

Suandy, Erly. 2014. Perencanaan Pajak Edisi 5. Penerbit : Salemba Empat, Jakarta.

Sunyoto, Danang. 2013. Metodologi Penelitian Akuntansi. Penerbit: PT. Refika Aditama, Bandung.

Waluyo. 2014. Akuntansi Pajak, Edisi 5. Penerbit: Salemba Empat, Jakarta. 